\title{
Apolipoprotein H Measurement
}

National Cancer Institute

\section{Source}

National Cancer Institute. Apolipoprotein H Measurement. NCI Thesaurus. Code C82003.

The determination of the amount of apolipoprotein $\mathrm{H}$ present in a sample. 